\title{
AZAM Tani: Improving the Knowledge Can Help Increased the Level of Skills Respondent in Work
}

\author{
Mohd Hudzairi Mansor Mohd Nadzir*, Mohd Yusof Hussain, Zaimah Ramli \\ School of Social, Development \& Environmental Studies (PPSPP), Faculty of Social Sciences and Humanities, National University \\ of Malaysia (UKM), Bangi, Malaysia \\ Email: ^hudzairi@gmail.com
}

How to cite this paper: Nadzir, M.H.M.M., Hussain, M.Y. and Ramli, Z. (2017) AZAM Tani: Improving the Knowledge Can Help Increased the Level of Skills Respondent in Work. Open Journal of Social Sciences, 5 , 63-72.

https://doi.org/10.4236/jss.2017.59005

Received: August 1, 2017

Accepted: September 3, 2017

Published: September 6, 2017

Copyright $\odot 2017$ by authors and Scientific Research Publishing Inc. This work is licensed under the Creative Commons Attribution International License (CC BY 4.0).

http://creativecommons.org/licenses/by/4.0/

\begin{abstract}
Poverty is not something new issue for a country. Poverty is seen as a problem that could negatively impact on a country. Malaysia also cannot escape from this poverty problem. Malaysia is a country where the Moslem people are majority and they are permanent resident. Therefore, from the perspective of Islam, poverty had been seen as a social disease [1]. According to the post' or scholars' statement, one of the ways poverty can be overcome is the implementation of the community development program. One of the community development programs in Malaysia that for farmer and house hold that involve in agriculture is called AZAM Tani. A study was conducted on participants AZAM Tani (Agricultural AZAM) areas of Seberang Perai, Penang. AZAM are words in Malay language. It is also short form and stand for End Time of The Poor. The method used was census. A total of 54 respondents were found. The results showed that the AZAM Tani program is able to help increase knowledge. Then with the knowledge that the participants had, they are able to raise their level of skills. This can be seen in the results of Spearman correlation indicating the relevance of knowledge to the implementation of the program and the relevance of relationship knowledge and skills with $r=$ $0.612, p<0.05$. This relationship is positive. The study also shows an increase in the income level of the respondents.
\end{abstract}

\section{Keywords}

Poverty, Knowledge, Skills, AZAM Tani

\section{Introduction}

Poverty is not something new issue for a country. Poverty is seen as a problem 
that could negatively impact on a country. Malaysia also cannot escape from this poverty problem. Malaysia is a country where the Moslem people are majority and they are permanent resident. Therefore, from the perspective of Islam, poverty had been seen as a social disease [1]. According to the post or scholars' statement, one of the ways poverty can be overcome is the implementation of the community development program. According to Haris B. Adb Wahab [2], a community development program is one of the government's in most of the third world plans to increase the standard of living for avoiding poverty. If you look at his states, this shows that the community development program can give benefit to the community in poverty eradication or later production of electronic products. These show that household in poverty have a chance to build life to more better and quality. In fact, they are able to experience life like other simple societies. They will also not be isolated from the flow of development to feel the enjoyment of existence in life.

In Malaysia, various programs implemented to ensure the eradication of poverty can be done best as possible. Bowen [3] states that the poor should get appropriate training and support. So that they can become more knowledgeable and helpful as community development partners and community leaders. With that approach, we can see that using the community development program is a good step. The concept of community development can only be realized through a program created by the government. So it has triggered community development program which aims to improve the socio-economic households in a community. However, in an effort to reduce poverty agency involved need to take three steps to a sustainable reduction [4]. Actionable reasons for poverty must be identified as the first step. Second, the program must be designed with a specific goal. The final determination of its operations and moving these programs to the people who most need this support [4].

This article also shows the history of the concept of community development in Malaysia. According to some study, the concept of community development in Malaysia has been created before independence. Based on Haris [5], concept of community development starts from 1930. After trial in Taiping around 1953, that truly show the concept development are existed and had been implantation in Malaya [5] [6]. Outright indicates that the concept of community development is geared to the development of the standard of living of individuals in a community. The main concern is the poor and the poorest (hard poverty). This can be seen in what is said by Sharina [7], one of the key strategies is community development through socio-economic aspects which can improve the living standards of the community. Even Bradshaw [8] also notes how every theory adopted poverty in policy discussions that regular and community development program is aimed at addressing the root causes of poverty.

After New Economy Policy (DEB) had been introduce by the second former Prime Minister and till the government under the leadership of Prime Minister Dato' Seri MohdNajib bin Tun Abdul Razak, there were community development program had been implemented in that period. The agencies involved are 
as KEMAS, Farmers Organization (Pertubuhan Peladang), Fisheries Development Authority and others. In line with the policy of Malaysia: People First, Performance Now, the government has emphasized on several things. One of the government target are well-being and standard of living of household. The launch of National Key Result Areas (NKRA) and the government transformation program reveal that the government is serious in its efforts to improve the lives of low-income people with the goal of reducing poverty. As the result, again a new community development program at the time.

One of the community development programs that concerns the author is AZAM Tani (Agriculture AZAM) program. The launch of this community development program was placed under the Ministry of Agriculture and Agro-Industry to manage it. The program is also a program of four programs under the project 1 AZAM (End Time of The Poor), where the program is located under the NKRA terrace. This program also for farmer and house hold that involve in agriculture AZAM are word in Malay language. It also short form and stand for End Time of The Poor.

The majority of program under project 1 AZAM were entrusted to the Ministry of Women, Family and Community Development. Actually this ministry is the core leader of the project 1 AZAM and had been entrusted under NKRA. The other three programs are AZAM Khidmat (Services), AZAM Kerja (Works) and AZAM Niaga (Business). This all program are to help the poor Malaysians out of the poverty [9]. If viewed directly, then the executor has set the target. These people are those who are eligible for assistance and will receive benefits to ascertain their goal of improving the standard of living can be achieved. They are low-income earners but preference to those who are poor.

Poverty people, household and individual in poverty are always seen as a person who lacks of knowledge and skills. They are associated with a low level of their education. This can be seen in the opinion of MohdTaib (in [10]) which states that persons engaged in poverty have a low level of education. Furthermore, that they also only have a limited ownership of productive inputs and productivity levels and low production levels. So in the end, the results show that their will have a low income only. Through the program AZAM Tani, it had its own objectives. One of its objectives is to increase the knowledge of participants. If the participants are able to increase the level of knowledge, it will also be able to increase their skill level as well. Thus the author would like to see that there is significant correlation between increasing knowledge and improving the skill level of the participants after their join the program. The study was then conducted on the AZAM Tani program participants in Seberang Perai area.

\section{Methodology}

Any study must have its own method. Methods of conducting research and obtaining relevant information are much needed. This section in this article will present the methods that been used to do this study. Mix method had been selected and used in this study. The author chooses this method because it combines 
two methods: quantitative and qualitative. The qualitative support the data that had been fine out using quantitative method. To collecting data, author use survey form. This study show the landscape of the study in form frequency and percentage data in table form. Not just only that, the Spearman correlation test also was used in this study. This study also is more to the descriptive study. Because it shows data more in table. Location of the study area is the Seberang Perai area containing three districts namely the North Seberang Perai (Seberang Perai Utara), the Central Seberang Perai (Seberang Perai Tengah) and the South Seberang Perai (Seberang Perai Selatan).

The size of population that involved in AZAM Tani as the participant for 2011 at the Seberang Perai area is 118 people. The total number of all the participants Azam Tani program for the year 2011 in the state of Penang is 248 people. But the study is only at the Seberang Perai area. So the judgmental and snow ball are the most appropriate method in this study. However, only 54 participants were found in that area through the method that had been carried out. This number is not included with the 10 participants who were used in the pilot study.

The instruments used are questionnaires (survey form) and literature review. In this survey form, there are part that author also interviews using spontaneous questions and note it on paper. Author also observes indirectly at the field, so that author can use it as information. It can support to data that had been analysis. In addition to using descriptive analysis, the author also conducted tests Spearman rho correlation ( $r$ ) in this research. This test is to test the strength of the relationship between the variables studied in each other. The test that will be show is between knowledge and skill. These are two components that are always used in work.

\section{Findings/Analysis}

Malaysia is a developing country. Reduce poverty not only as a part of the policy made by government. It is also responsible to help them that in trouble in living example live in poverty. For this situation, many ways that had been try by the government. One of it, is by using community development program. The implementation of community development programs is necessary to assist the country in its development towards the developed country. The cooperation of the community and the government is necessary to ensure that the program runs successfully. Maimun [in. [2]] stated that community development is an initiative by the community in collaboration with external parties to empower individuals and groups in society through the activities undertaken. The author see that AZAM Tani program is another step to ensure that the community development concept can be carried out, so it can help to further empowerment the society. In fact, it is an effort to avoid people dropping out of the mainstream of development as a result of poverty.

This section will show the results of the study. Authors have been obtained from the field study. Initial of this section, the author will touch a little about 
demography of respondent. It also concerned for this study. All 54 respondents involved in AZAM Tani are from ethnic Malay and Muslim. All of these respondents are low-income before joining AZAM Tani. More than half of respondents had level study until a secondary school and end in that stage. The percentage is 55.6 percent. Some of them never take the Sijil Pelajaran Malaysia in Table 1. Only one person that involve in this program, had never been to school. If seen in this analysis, the majority of respondents can read and are not illiteracy. In fact, they also have the mathematic basic.

Majority of respondents that involved in this study were male and have married. For Table 2, it shows the analysis of the respondents according to their age. If you look at the percentage of respondents aged between 46 years to 50 years is highest value of percentage in that table where the percentage are at level 37 percent. While then, the percentage of respondents aged between 36 years to 40 years and 56 year to 60 years showed a low percentage. From here we can see that people aged over 46 years to 50 years dominating in the AZAM Tani program participants. This shows that the majority of respondents still can add to knowledge because they are not elderly. Seniors are defined as those aged 60 years and over [11]. However, this age group also needs to actively improve their lives if they are in poverty.

After showed the demography of respondent, now let see the analysis of Spearman correlation test relating to the implementation AZAM Tani program and knowledge. If seen in Table 3, it shows that there is a correlation between the implementation of the program and the level of knowledge AZAM Tani participants to enhance the performance of respondents AZAM Tani itself. This can be see, when the result $r=0496, p<0.05$. This positive relationship shows that

Table 1. Analysis of education.

\begin{tabular}{ccc}
\hline & Frequency & Percent \\
\hline No schooling & 1 & 1.9 \\
Primary School & 23 & 42.6 \\
Secondary School/High School & 30 & 55.6 \\
Total & 54 & 100.0 \\
\hline
\end{tabular}

Table 2. Analysis of respondents by age.

\begin{tabular}{ccc}
\hline Age & Frequency & Percent \\
\hline $36-40$ & 4 & 7 \\
$41-45$ & 9 & 17 \\
$46-50$ & 20 & 37 \\
$51-55$ & 12 & 22 \\
$56-60$ & 4 & 7 \\
$61-65$ & 5 & 9 \\
Total & 54 & 100 \\
\hline
\end{tabular}


Table 3. Correlation test view power relationship between knowledge and program implementation.

\begin{tabular}{ccccc}
\hline & & & $\begin{array}{c}\text { Program } \\
\text { implementation }\end{array}$ & Knowledge \\
\hline $\begin{array}{c}\text { Spearman's } \\
\text { rho }\end{array}$ & $\begin{array}{c}\text { Program } \\
\text { implementation }\end{array}$ & $\begin{array}{c}\text { Correlation } \\
\text { Coefficient } \\
\text { Sig. (2-tailed) }\end{array}$ & 1.000 & $0.496\left(^{* *}\right)$ \\
& $\mathrm{N}$ & $\cdot$ & 0.000 \\
& Knowledge & $\begin{array}{c}\text { Correlation } \\
\text { Coefficient }\end{array}$ & $0.496\left({ }^{* *}\right)$ & 54 \\
& Sig. (2-tailed) & 0.000 & 1.000 \\
& $\mathrm{~N}$ & 54 & 54 \\
\hline
\end{tabular}

${ }^{* *}$ Correlation is significant at the level of 0.01 (2-tailed).

there existed significant between the variable in this community study. Respondents of AZAM Tani take advantage of opportunities that have been given for they in this program to increase their knowledge.

In the implementation of this program, respondents joining this AZAM Tani program want to acquire the knowledge to improve their work performance. It also takes the efforts and initiatives of the respondent itself so they can success in improving knowledge. So here we can see that the AZAM Tani program beneficial to the respondents in improving their level of knowledge. In fact, by increasing the level of knowledge it also could help to increase the skill level of respondents indirectly. This can be seen in the second Spearman correlation test. This test can be seen in Table 4 .

The results of this second test based on Table 4. It showed the results of the analysis of Spearman correlation test between knowledge and skills. The test show that exist significant relationship between the level of knowledge and skill in the performance of participants AZAM Tani $(\mathrm{r}=0.612, \mathrm{p}<0.05)$. This positive relationship indicates that exist in this study population, show that AZAM Tani respondents really needed to increase knowledge so that they can increase their skills in work. This can be translated in Figure 1 are listed below. By increasing the level of knowledge and skills, there are respondent who received the new economic opportunities and it can be made as main work or additional work. This is to double their income and give benefit to themselves.

The results have shown that there is a positive relationship between the AZAM Tani Program to increase knowledge after got aid from AZAM Tani. This may have happened because the courses provided by the organizer. In addition, the background level of education of the respondents may cause the respondent easily understand the information or knowledge that is shared by the executive.

Nevertheless involvement seriously by the participants is also necessary to ensure that all participants managed to increase revenue. Effort is necessary in trying to improve their knowledge and skills. Through the knowledge and skills 
Table 4. Correlation test See power relationship between knowledge and skills.

\begin{tabular}{ccccc}
\hline & & Knowledge & Skills \\
\hline Spearman's rho & Knowledge & Correlation Coefficient & 1.000 & $0.612\left({ }^{* *}\right)$ \\
& & Sig. (2-tailed) & $\cdot$ & 0.000 \\
& Skills & Correlation Coefficient & $0.612(* *)$ & 1.000 \\
& Sig. (2-tailed) & 0.000 &. \\
& $\mathrm{~N}$ & 54 & 54 \\
\hline
\end{tabular}

${ }^{* *}$ Correlation is significant at the level of 0.01 (2-tailed).

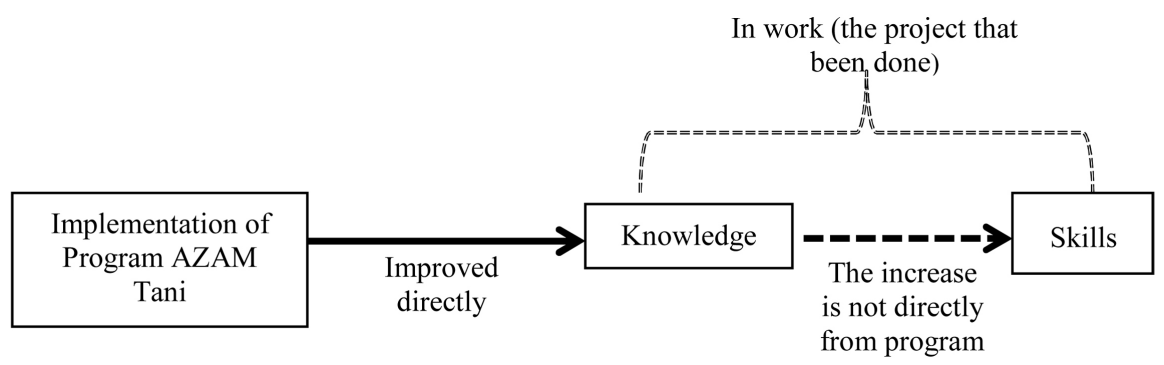

Figure 1. Increasing skills at work indirectly through AZAM Tani program.

can help improve work performance and labor productivity in the production to the optimum level. And also the knowledge and skills must related to what work respondents are doing. This is to ensure that the program is carried out successfully with a full agenda and poverty reduction can be achieved. Respondents also need to seriously involve in AZAM Tani program and they also need to have effort to achieve what they want in their life. So in future, the respondents will not dependent to government aid any more. And this will help more to reduce the poverty index.

Like Kwok Chin Hoe and Haris [12] says, commitment and active participation of local communities also are needed to eradicate poverty. The active of them in personally will help more to the success of program that had been develop to reduce poverty. As according B. Taman Achda and Anharddin Komari [13] stated that community development is not a process that is shaped and processed from the top, it should be implemented at the grassroots of society subordinates. The authors refer to the cooperation of the respondents and their business or project is also important to ensure the AZAM Tani program entirely successful. However, author see that AZAM Tani are useful to respondents in way develop knowledge, skill and competitiveness. But it must put other step to make AZAM Tani more successful.

\section{Conclusions}

Malaysia is a developing country and it is in process to be a developed country. To avoid slipping of the planned development, the issue of poverty needs to be 
addressed. Even with the action through the community development programs, it still can be seen as a one of the appropriate actions. This can be seen in the AZAM Tani Program at Seberang Perai section. It assists participants in improving revenue by increasing the level of knowledge. This can be seen in statement by MohdNor Ghani [14], he just say that the creation of economic opportunities and jobs would not benefit the poor if they are not given the knowledge and retraining. The new opportunities had been provided. The poor people just need to take the opportunities that have been given to them. However, Trier [15] had said that poor people should have some access to some resources to survive and will continue to move out from poverty. The author sees knowledge as one of access to the poor and also to help them improve their skills. This is one way but gets two accesses to the keys to success in work.

The analysis has shown that there is a significant correlation between the implementation of the AZAM Tani program with an increased level of knowledge of respondents to make their performance in work better. This will help them to success in their project. There were also participants who are able to create new economic opportunities. In fact, there are respondents who can perform additional work. However the author concluded that by increasing the level of knowledge of participants AZAM Tani had found also indirectly skills can also be improved. This summarized the results of Spearman correlation test which showed a significant relationship between the level of knowledge and level of skills of the respondents after joining the AZAM Tani program. Significant value are $r=0.612, p<0.05$. AZAM Tani program benefits the participants in fact increase the level of knowledge through increasing the level of knowledge it can also help to increase the skill level of participants indirectly.

Thus the author believes that the basic of the AZAM Tani program showed that being involved in and participating in this program, respondents managed to increase the level of their own knowledge and skills. Despite the increase in the level of skills is not in directly way from the program, but it only indirectly way from program through knowledge. However, implementing this AZAM Tani program proved to contribute to the improvement of the majority of participants AZAM Tani in Seberang Perai. Anyhow, the success of this program needed the involved of respondents effort with a vengeance. The implementers need to plan carefully and look at the needs of the present to create more useful ways to participants AZAM Tani program. The community development program in future must be more detailed in planning, also putting or combining more steps in program, such as adding a microcredit and Religious talk. Finding the best way and the useful can make the program more success. This is similar to what was said by Dani [16] that development of a successful community is one of the country's development strategy through programs organized. All agencies and participants need to work together. Other than that, non-government agencies like private sector also need to help share knowledge or skill with government agencies to make AZAM Tani success. Although improvements in skills 
are not directly, it happens indirectly through the knowledge that comes after joining the program.

\section{Acknowledgements}

Mohd Hudzairi, M. M. N would like to thank Ministry of Agriculture and Agro-Based Industry Malaysia and FAMA Penang for providing relevant references via online and hardcopy. Also thanks to respondents that participate in this research. Also to National University of Malaysia (UKM) and Ministry of Higher Education for allocated the funding threw scholarship to Mohd Hudzairi, M. M. Nto done this research. Also special thank Mohd Yusof Hussain and Zaimah Ramli for always guiding Mohd Hudzairi, M. M. N to complete this research.

\section{References}

[1] Abdullah, H. (1984) Kemiskinan Dan Kehidupan Golongan Rendah. Universiti Kebangsaan Malaysia, Bangi.

[2] Haris Abd.Wahab dan Abd. Hadi Zakaria. (2012) Penilaian Keperluan dalam Pembangunan Komuniti. Penerbit Universiti Malaya, Kuala Lumpur.

[3] Bowen, G.A. (2007) An Analysis of Citizen Participation in Anti-Poverty Programmes. Community Development Journal, 43, 65-78.

https://doi.org/10.1093/cdj/bsm011

[4] Krishna, A. (2007) For Reducing Poverty Faster: Target Reasons before People. World Development, 35, 1947-960. https://doi.org/10.1016/j.worlddev.2006.12.003

[5] Adb Wahab, H.B. (1996) Penglibatan Peserta Dalam Program Pembangunan Komuniti Di Kampung Buloh, Kelantan. Master Thesis, Fakulti Ekologi Manusia, Universiti Pertanian Malaysia, Serdang.

[6] Abi Samah, A. (1988) Kemas, Pembangunan Komuniti Dan Kemiskinan: Satu Kajian Kes di Daerah Jasin, Melaka. Master Thesis, Institut Pengajian Tinggi, Univerisit Malaya, Malaysia.

[7] Halim, S.A. (2010) Kelestarian Kehidupan Dalam Arus Pembangunan Pelancongan Kajian Penyertaan Komuniti Tempatan Di Pulau Langkawi. Ph.D. Thesis, Universiti Kebangsaan Malaysia, Bangi.

[8] Bradshaw, T.K. (2005) Theories of Poverty and Anti-Poverty Programs in Community Development. Rural Poverty Research Centre Working Paper No. 06-05. http://www.rupri.org/Forms/WP06-05.pdf

[9] Nor, R. and Azhar, S. (2016) 1 AZAM Aiding Low-Income Households in Malaysia. Journal of Human Resource and Sustainability Studies, 4, 293-304. https://doi.org/10.4236/jhrss.2016.44029

[10] Abu Bakar, N.R. and Awang, A.H. (2012) Memperkasakan Komuniti Desa Melalui Aktiviti Keusahawanan. Junaenah Sulehan dan Noor RahamahHj Abu Bakar (pnyt.). Penyertaan dan Pemerkasaan Komuniti Desa Malaysia-Indonesia, hlm. Penerbit Universiti Kebangsaan Malaysia, Bangi, 23-39.

[11] Masyarakat, J.K. and Negara, D.W.E. (2016) http://www.jkm.gov.my/jkm/index.php?r=portal/left\&id=WjFUdFBURTV0Zis0N0 NxYm05Qk9XQT09

[12] Hoe, K.C. and Abd Wahab, H. (2013) Sokongan Politik dan Penglibatan Masyarakat Dalam Program Pembasmian Kemiskinan di Sarawak. Malaysia Journal of Society and Space, 9, 89-97. 
[13] Achda, B.T. and Komari, A. (2012) Konsep Dan Pendekatan Pembangunan Komuniti. Junaenah Sulehan dan Noor Rahamah Hj Abu Bakar (pnyt.). Penyertaan dan Pemerkasaan Komuniti Desa Malaysia-Indonesia, hlm. Penerbit Universiti Kebangsaan Malaysia, Bangi, 23-39.

[14] Ghani, M.N. (1984) Dimensi Kemiskinan Dan Rancangan Pembasmian Kemiskinan. Dlm. Amir HussinBaharuddin (pnyt.). Siri Kumpulan Esei: Ekonomi Pembangunan. hlm. Dewan Bahasa dan Pustaka, Kuala Lumpur, 129-154.

[15] Strier, R. (2009) Community Anti-Poverty Strategies: A Conceptual Framework for a Critical Discussion. British Journal of Social Work, 39, 1063-1081. https://doi.org/10.1093/bjsw/bcm149

[16] Salleh, D. (2004) Pengenalan. Dlm. DaniSalleh (pnyt.). Pembangunan Komuniti: Dasar, Konsep, Strategi Dan Isu Di Malaysia, hlm. ix. Penerbit Universiti Utara Malaysia, Sintok.

Submit or recommend next manuscript to SCIRP and we will provide best service for you:

Accepting pre-submission inquiries through Email, Facebook, LinkedIn, Twitter, etc. A wide selection of journals (inclusive of 9 subjects, more than 200 journals)

Providing 24-hour high-quality service

User-friendly online submission system

Fair and swift peer-review system

Efficient typesetting and proofreading procedure

Display of the result of downloads and visits, as well as the number of cited articles

Maximum dissemination of your research work

Submit your manuscript at: http://papersubmission.scirp.org/

Or contact jss@scirp.org 